\title{
Intraseasonal variability of low-level moisture transport over West Africa
}

\author{
M. Issa Lélé ${ }^{1}\left[\right.$ ] Lance M. Leslie $^{1,2}$
}

Received: 17 June 2016 / Accepted: 23 August 2016 / Published online: 16 September 2016

(C) The Author(s) 2016. This article is published with open access at Springerlink.com

\begin{abstract}
The vertically integrated surface- $850 \mathrm{hPa}$ atmospheric water vapor flux is investigated, to account for the total low-level moisture flux contribution to rainfall over West Africa (WA), based on NCEP-NCAR reanalysis data. The focus is the contributions to total moisture transport and convergence by the mean circulation, the synoptic ( $<10$ days), and climate ( $>10$ day) scale anomalies. For WA, the time-mean flow and climate anomalies are comparable. Similarly, for meridional and zonal components, transports by the time-mean and climate anomalies are the largest contributors to mean meridional and zonal moisture transport. While the climate anomalies are responsible for driving moisture poleward from the Atlantic Ocean to the Guinea coast, and westward from the western Atlantic Ocean into the Sahel, the synoptic anomalies contribute to transporting moisture zonally out of the Sahel. Moreover, the spatial distribution of moisture flux convergence reveals a close similarity to the observed 2005 relatively wet and 2006 relatively dry accumulative rainfall. Convergence in WA is mainly the result of moisture transport by the mean flow. An enhanced (weak) flux convergence by
\end{abstract}

This paper is a contribution to the special issue on West African climate decadal variability and its modeling, consisting of papers from the West African Monsoon Modeling and Evaluation (WAMME) and the African Multidisciplinary Monsoon Analyses (AMMA) projects, and coordinated by Yongkang Xue, Serge Janicot, and William Lau.

M. Issa Lélé

missalele@gmail.com

1 Cooperative Institute for Mesoscale Meteorological Studies, The University of Oklahoma, 120 David L. Boren Boulevard, Suite 2100, Norman, OK 73072-7304, USA

2 School of Meteorology, The University of Oklahoma, Norman, OK 73072, USA the mean flow is characteristic of wet (dry) Sahel rainfall seasons. During wet April-June rainy seasons in the Guinea coast, enhanced convergence due to synoptic anomalies is observed in the region, whereas it is suppressed during dry April-June seasons. In the Sahel, however, during the dry rainy seasons, the convergence region due to synoptic anomalies is displaced southward.

Keywords Moisture transport - West African moisture variability

\section{Introduction}

Monsoons are key aspects of both the regional and general circulation of the atmosphere. For this reason, the major monsoon systems throughout the world have been extensively studied in recent decades. It is recognized that the major forcing of monsoons is the thermal contrast between the continent and the ocean, with moist processes and the Earth's rotation also being important factors (Trewartha and Horn 1980; Webster 1987; Rodwell and Hoskins 1996; Zheng 1997; Loschnigg and Webster 2000). Although some progress has been made in understanding the causes of large-scale monsoon variability, many aspects of their circulation as well as their influences on rainfall are still not fully understood, and much remains to be done in the modeling and quantitative prediction of monsoon rainfall events, especially in West Africa (WA). This has led to the initiation of the African monsoon multidisciplinary analysis (AMMA), which is an international project intended to improve our knowledge and understanding of the West African monsoon (WAM) and its variability across different time-scales (e.g., Redelsperger et al. 2006). 
Understanding the causes of small-to-large-scale climate anomalies is necessary for predicting the WAM variability. Consequently, several regional and large-scale atmospheric features have been studied. Accordingly, the Sahelian droughts have been related to either the weakening or disappearance of the individual or collective key atmospheric features controlling the rainfall variations over WA (e.g., Xue and Shukla 1993; Hodges et al. 2003; Xue 1997; Le Barbé and Lebel 1997; Clark et al. 2001; Cook and Vizy 2006; Bell and Lamb 2006). Among them are the sources and transport of water vapor. Because the water cycle is an integral part of the global energy cycle, it therefore plays a fundamental role in determining the large-scale circulation and precipitation patterns. In addition, the variability of water availability is one of the most limiting parameters for sustaining life, agriculture, and economic development in the Sub-Saharan WA countries (Lélé et al. 2015). Therefore, understanding the WAM climate fluctuations requires an accurate estimation of the hydrological cycle over the region and its linkages to regional-scale features. However, this water cycle is poorly understood, partly because of its complex web of feedbacks and because it operates over a wide range of time and space scales. Accordingly, extensive numerical modeling experiments (Biasutti et al. 2008) have concluded that the causalities of Sahelian rainfall variability are not yet well known.

Previous moisture flux analyses have focused on the large-scale forcing mechanisms in relation to the initiation and maintenance of the Sahelian long-term drought. For example, Long et al. (2000a) examined moisture flux and vertical motion data, and concluded that changes in the general circulation are important in initiating drought in the Sahel, although other mechanisms may be responsible for its persistence. Fontaine et al. (2003) studied the atmospheric water cycle and associated moisture fluxes in the WAM region, using the NCEP-NCAR reanalysis data. Their study identifies the Mediterranean Sea, Central Africa, and the Gulf of Guinea as sources of low-level moisture for the WAM region. The authors also noted the importance of the meridional and zonal moisture fluxes for interannual rainfall variability, with the zonal moisture flux being the most important for the Sahelian region. Couvreux et al. (2010), used observations and the ECMWF reanalysis dataset to underscore the variability of the northward excursions of the moisture flux on the 3-5 days time-scale. Similarly, Grams et al. (2010) studied the sea breeze-like inflow from the eastern Atlantic via Mauritania into the southwestern part of the Saharan heat low (SHL). They found that the so-called Atlantic Inflow regulates the penetration of moist air into WA.

Meynadier et al. (2010a) show that WA acts as a moisture source rather than a sink during the summer. As for other tropical regions, there are large biases in the WAM region in climate models (e.g., Agustí-Panareda et al. 2010; Xue et al. 2010; Bock et al. 2011) mainly associated with the parameterization of physical processes. The annual cycle of water vapor transport over WA associated with the regional circulation was investigated by Thorncroft et al. (2011). They found that the monsoon southerly flow is established between the Atlantic cold tongue and the heat low. The cold tongue regulates the timing and intensity of coastal rainfall in the spring, whereas the heat low brings moisture into the continent. Mera et al. (2014) studied the variability and transport of surface moisture in WA using NCEP global model analyses, satellite, and station observations during the spring, which revealed that the Northeast Atlantic, the Gulf of Guinea, the South Atlantic, North Africa, and the Mediterranean Sea are moisture sources for WA during the February-June period.

The present efforts aimed at understanding the intraseasonal moisture flux variability and potential predictability of the WAM precipitation variability are motivated by the fact that the associated weather (e.g., heavy rain, drought, strong surface winds) poses a serious threat to the lives of the citizens, and impacts the economies of the countries of the region. Previous moisture transport studies over Africa have used short observational records mainly because of the limited number of available sounding observations. It has long been suspected that the South Atlantic Ocean serves as the major source of water vapor for rainfall in both the Guinean, and Sahelian land regions. This study aims at advancing the present understanding of the sources of moisture for rainfall in WA. In addition, it is intended to provide quantitative estimates of the separate contributions of the transport by synoptic and climate anomalies, defined as time-varying departures from the seasonally mean state and split into high-frequency (periods $<10$ days) and low-frequency (periods $>10$ days) components (e.g., Newman et al. 2012). This analysis allows an investigation of: (i) the role of changing major regional circulation systems and their relationships to moisture fluxes associated with rainfall on intraseasonal time-scales; and (ii) the identification of potential predictors for monsoon onset and withdrawal over WA.

In this study, the numerical analyses of the NCEPNCAR are used to compute the atmospheric water vapor flux and flux convergence. The average seasonal distribution is interpreted in terms of the atmospheric circulation due to the mean flow, the climate (low frequency), and synoptic anomaly. Finally, values of the summer monsoon total moisture flux convergence are examined with respect to direct measurements of the 2005 and 2006 season accumulated precipitation. Section 2 describes the data and methods used. Section 3 investigates the mean moisture budget variability. Sections 4 and 5 present the relationship between moisture flux convergence and precipitation, and Sect. 6 provides the conclusions. 


\section{Data and methods}

\subsection{Data}

The observational rainfall dataset used in this study was provided by the national meteorological centers of countries across the region (see Lélé et al. 2015). As many as 180 rain gauge-based precipitation observations over WA were used. The data were quality controlled, with values exceeding physically reasonable limits being excluded. The majority of the station records were incomplete, with considerable variations in the lengths of continuous observations and the presence of gaps in the records. Because no attempt was made in this study to estimate missing values, the 180 stations selected were those with the most complete and reliable records.

The National Centers for Environmental PredictionNational Center for Atmospheric Research (NCEP-NCAR) reanalysis dataset is used in analyses of atmospheric circulation (Kalnay et al. 1996). We chose this dataset because it has been used in numerous studies of atmospheric dynamics over Africa (e.g., Nicholson and Grist 2003; Nicholson and Webster 2007; Nicholson 2008) and selected results have been verified with WA pibal and rawinsonde data (Grist and Nicholson 2001). However, there are uncertainties in some variables. For example, wind fields from NCEP-NCAR reanalysis are considered to be relatively reliable, but there are difficulties with tropical divergence circulations and rainfall (Poccard et al. 2000; Kinter et al. 2004). For this reason, the NCEP-NCAR dataset are divided into three categories. The most reliable variables are Type A variables, and are strongly influenced by the observations. These include zonal and meridional wind components. Type B variables, however, are influenced by both the observations and the model. Among this category are the low-level winds and the specific humidity. Type $\mathrm{C}$ variables (e.g., precipitation) are completely determined by the model. Over Africa, more emphasis frequently is placed on model forecasts because of the limitations imposed by the lack of observations, especially radiosonde observations. However, despite the progress in the WA modeling, there are still some errors in the simulated WAM precipitation events (e.g., Xue 1997; Giannini et al. 2003; Hoerling et al. 2006, 2010; Lau et al. 2006; Yoshioka et al. 2007; Caminade and Terray 2010; Agustí-Panareda et al. 2010; Xue et al. 2010; Meynadier et al. 2010b; Bock et al. 2011; Martin and Thorncroft 2014; Xue et al. 2016). Moreover, biases in both the observations and the models are known to introduce spurious variability and trends into the NCEPNCAR reanalysis (e.g., Bock and Nuret 2009; AgustíPanareda et al. 2010). In this study, the NCEP-NCAR variables used are both Type A, and B. Consequently, results from such analyses should be considered with due caution.

\subsection{Vertically integrated moisture flux}

The equation generally used to describe the atmospheric moisture budget in Eulerian specification is:

$\frac{\partial \bar{w}}{\partial t}+\nabla \cdot \bar{Q}=\bar{E}-\bar{P}$

where $w$ is the precipitable water, $E$ is evaporation from the surface, $P$ is the net surface precipitation rate, and $Q$ is the vertically integrated moisture flux (e.g., Peixoto and Oort 1992). An overbar denotes the time average. $Q$ is computed using analysis or reanalysis wind and humidity fields in many recent studies (e.g., Wang and Paegle 1996; Mo and Higgins 1996; Mo et al. 2005; Schneider et al. 2006; Bielli and Roca 2009; Trenberth et al. 2007, 2011; Newman et al. 2012). This is because of the agreement among reanalyses for $Q$ computed as a residual from Eq. 1, rather than for $Q$ computed from the reanalysis estimates of $P$ and $E$ (e.g., Trenberth et al. 2011). Hence, in pressure coordinates,

$Q=\frac{1}{g} \int_{p_{u}}^{p_{s}} \boldsymbol{V} q d p$

where $q$ is the specific humidity, $\boldsymbol{V}$ is the vector wind, $\mathrm{g}$ is the acceleration due to gravity, $P_{s}$ is the surface pressure, and $P_{u}$ is the pressure above which the flux and flux divergence become zero. For the long-term mean, the tendency is negligible; hence the mean moisture budget is a balance between moisture flux divergence and the water sources/ sinks:

$\nabla \cdot \bar{Q}=\bar{E}-\bar{P}$

Following Newman et al. (2012), the moisture budget is partitioned into different time scales defined by:

$\bar{Q}=\bar{v} \bar{q}+\overline{v^{c} q^{c}}+\overline{v^{s} q^{s}}$,

where the superscripts indicate climate (c) or low frequency and synoptic (s) time-scales. Hence, $\bar{Q}^{m}=\bar{v} \bar{q}$ represents the mean transport, $\bar{Q}^{c}=v^{c} \bar{q}^{c}$ the transport by the climate anomalies or low frequency transport, and $\bar{Q}^{s}=v^{s} \bar{q}^{s}$ indicates the synoptic transport. No attempt was made to analyze the contribution of the eddy flux and mean flux terms separately. Because moisture fluxes in the WAM region is concentrated in the lower altitudes (e.g., Lamb 1983; Cadet and Nnoli 1987; Bielli and Roca 2009; Pu and Cook 2012; Lélé et al. 2015), only the lower level moisture flux of the surface- $850 \mathrm{hPa}$ layer is considered in this study. 
Fig. 1 The local wavelet power spectrum (shaded, Units: $\mathrm{mm}^{2}$ $\mathrm{day}^{-2}$ ) of moisture flux divergence across the $\mathbf{a}$ western and c southern lateral boundaries of the Sahel during the 1960-2010 period using the "Morlet" wavelet. The areas below the thick solid curve indicate the "cone-of-influence", where edge effects become important. The thick black contours in the wavelet spectrum indicate that the power is statistically significant at the $95 \%$ confidence level using the white noise background spectrum. $\mathbf{b}, \mathbf{d}$ are the global wavelets which are time averaged wavelet spectra

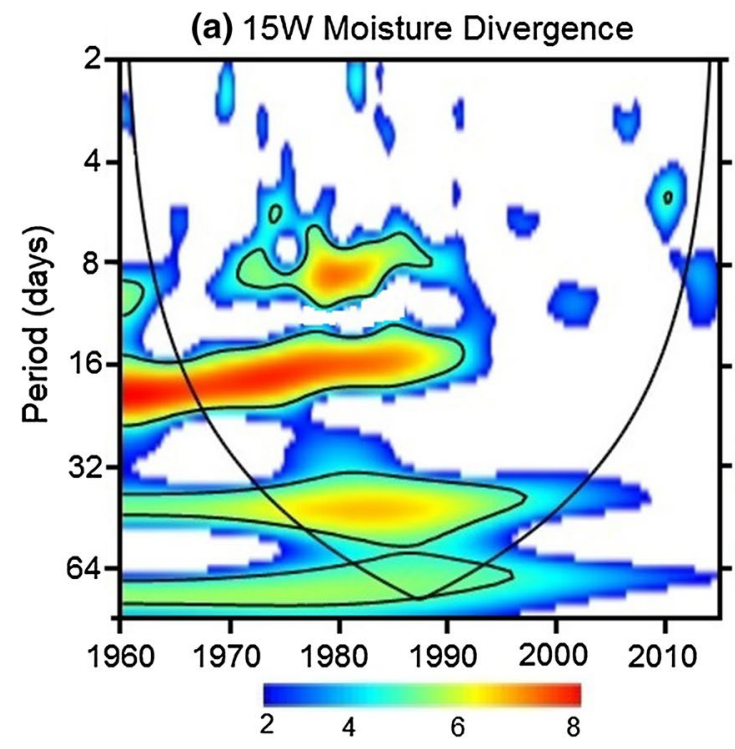

(b) Global Wavelet


(d) Global Wavelet

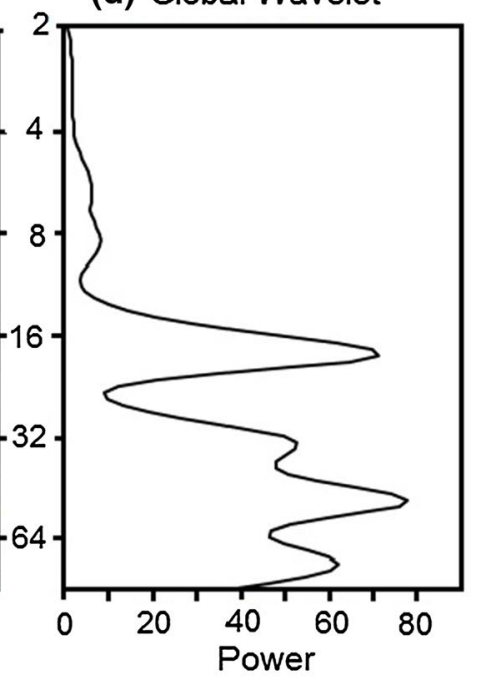

A wavelet analysis was performed to characterize the evolutionary behavior of moisture flux periodicity for the interval 1960-2010. Whereas the meridional flux is evaluated along southern $\left(5\right.$ and $10^{\circ} \mathrm{N}$ boundaries, the zonal flux is evaluated along the west $\left(15^{\circ} \mathrm{W}\right)$ and east $\left(15^{\circ} \mathrm{E}\right)$ boundaries. These boundaries were chosen according to WA climatic airflow patterns, and they account for most of the total inflow from the moisture sources (Lélé et al. 2015). Figure 1 shows the wavelet power spectrum for the moisture flux along $15^{\circ} \mathrm{W}$ and $10^{\circ} \mathrm{N}$ of the Sahelian region. The wavelet power spectra represents the changes of wavelet power in terms of scale with respect to time. The results show a wide spectrum of variability ranging from seasonal to subseasonal with substantial variability on synoptic, weekly, and monthly timescales. For example, in Fig. 1a, three significant spectral peaks for moisture divergence exist at the intraseasonal time-scale. One spectral peak shows periods of enhanced sub-weekly (8-9 day) variability probably associated with African easterly waves (Burpee 1975). Recent studies also have indicated the existence of periodicity between 6 and 9 days in the mid-tropospheric circulation over WA (Viltard et al. 1998; Diedhiou et al. 1999). Another spectral peak is centered on 15-day and may be related to the 10-25 day variability in WAM highlighted in other studies (e.g., Janicot and Sultan 2001; Grodsky and Carton 2001; Sultan et al. 2003; Lavaysse et al. 2006; Maloney and Shaman 2008). Significant power also emerges in the flux time series of the western and southern boundaries of Sahelian zone, with the 30-60 day band being its characteristic periodicity (Fig. 1a, c). The 30-60 day power spectrum attains its maximum during the mid-1960s, which corresponds to a period of declining Sahelian rainfall. 
The global spectrum analysis primarily shows the existence of three distinct time-scales of variability. One less than 10-days denoted in this study as the synoptic transport time-scale and the two other about 16 and 35-days respectively indicating the transport by the climate anomalies. Calculating each term of the Eq. 4 in this manner allows the quantification of the contribution from the high and low frequency moisture flux variations that characterize the WAM. The objective is to highlight the importance of local evaporation and remote moisture transport in regulating the interannual variation of West African summer rainfall. The separation of moisture transport into scales $<10$ day (synoptic scales) to those $>10$ day (large scales) is well suited for the climate of the region. This is because the West African mesoscale convective systems, as well as the local circulation effects such as mountain circulation and or sea breezes, is manifested at synoptic scales, whereas circulations associated with the AEJ correspond to the large scale.

\section{Mean atmospheric moisture budget variations over West Africa}

\subsection{Seasonal moisture transport}

Figure 2 shows the 1960-2009 mean moisture flux transport (vectors) and associated flux divergence (shading) for the June-September (JJAS) season. Each panel of Fig. 2 shows the flux transport terms in Eq. 4. Hence, Fig. 2a represents the total mean atmospheric moisture transport $(\bar{Q})$ and divergence and its associated divergence. This is the sum of the moisture transport and divergence of the other terms of Eq. 4. The transport by the mean flow is presented in Fig. 2b, while the low-frequency transport or transport by the climate anomalies and its divergence is shown in Fig. 2c, followed by the synoptic transport in Fig. 2d. As stated above, the main balance of the atmospheric water budget is between the moisture flux divergence and water sources/sinks. This because, for a sufficiently long period, the precipitable water is negligible. Therefore, in Fig. 2, $\nabla \cdot \bar{Q}$ is nearly equal to $\bar{E}-\bar{P}$, and the main moisture flux divergence displays a pattern similar to that of precipitation.

Large moisture sources are found over the tropical South Atlantic Ocean and to some extent over the Northeast Atlantic, whereas areas of moisture sinks are found over the continent with two maxima (Fig. 2a) centered over the Guinean coast and the Sahel respectively. The transport patterns shown in Fig. 2 are similar to those describe in Lélé et al. (2015) and other studies. The first, consists of a crossequatorial southwesterly flow across the Guinean coast, known as the WAM and is associated with the WA summer rainy season. Most of the northward WAM flow into the Sahel originates from the Gulf region, and its northward extension in July-September is determined by the location of the Saharan heat low (Thorncroft et al. 2011). The second is the westerly moisture flow near $8^{\circ} \mathrm{N}$ latitude, and has a major inflow directed from the eastern Atlantic Ocean onto the west coast of the Sahelian zone. This flow pattern has been recognized as a fundamental feature of the rainfall cycle over the Sahelian region (e.g., Kidson 1977; Cadet and Nnoli 1987; Druyan and Koster 1989; Cook 1999; Grams et al. 2010; Thorncroft et al. 2011), and was associated with the West African westerly jet (WAWJ; Pu and Cook 2012).

The total field is dominated by the contribution from the mean circulation. Moisture transport and divergence by the mean flow (Fig. 2b) is an order of magnitude higher than that of the other two components. But, the transport and divergence by climate anomalies (Fig. 2c) are larger than that of the synoptic transport and divergence (Fig. 2d). This suggests that the dominant scale of atmospheric water budget is large scale, in agreement to Bielli and Roca (2009). Significant contributions from the synoptic transport are generally seen over the higher topographic regions. The long-term seasonal averaged total convergence of the vertically integrated water vapor flux, represents all the essential features of the climatological rainfall accumulation distribution. For instance, an enhanced moisture flux convergence in the Sahelian region is generally associated with a weakening of the flux convergence in the Guinea region. Along the southwestern coast of WA there is some evidence for a region of increased convergence similar to the belt of higher rainfall observed over the Guinean Highlands. In the Gulf of Guinea region, the very small moisture flux convergence is consistent with the observed very low to zero rainfall often referred to as "the little dry season" (Lélé et al. 2015).

\subsection{Meridional transport}

The spatial distribution of each term contributing to the mean meridional moisture transport is presented in Fig. 3 as a function of time. The solid magenta line corresponds to the mean latitude position of the intertropical front (ITF). This is the limit of the southwesterly monsoon flow extent over WA and, therefore, provides an important parameter to describe the WAM variability (e.g., Lélé and Lamb 2010; Lélé et al. 2015). The meridional transport patterns are well defined, with predominantly poleward transport throughout the season, and its northernmost limit coincides with the latitude of ITF. The transport by the mean flow (Fig. 3b) dominates the total meridional moisture transport. Primarily, it is northward from the southern hemisphere but with a cross-equatorial component toward the WA landmass near the equator with a southwest orientation. Two maxima of meridional transport are observed. One occurs during the 

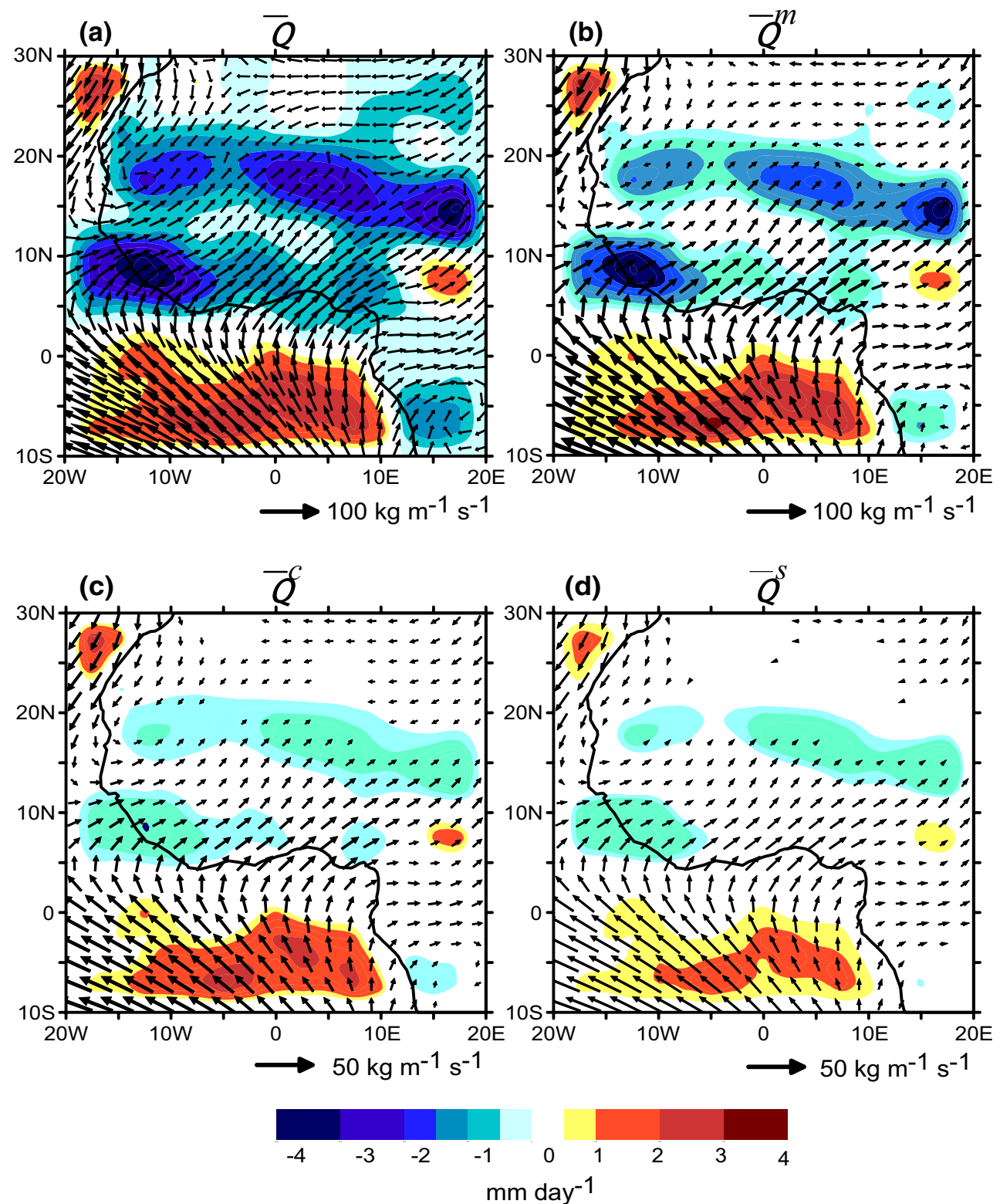

Fig. 2 Moisture transport (vectors) and its divergence (shading) for June-September of 1960-2009 for a the total flow, b by the mean flow, c by climate anomalies, and $\mathbf{d}$ by synoptic anomalies. Moisture transport vectors are in units of $\mathrm{kg} \mathrm{m}^{-1} \mathrm{~s}^{-1}$, and moisture divergence is in mm day ${ }^{-1}$

spring (May-June) season, near the equator, consistent with the observed large-scale region of enhanced precipitation over the area. The other, centered on $5^{\circ} \mathrm{N}$ occurs during the summer season and associated with the enhancement of precipitation over the Sahelian region in the July-September period.

The breakdown of the total meridional moisture transport into components due to mean flow, climate, and synoptic anomalies reveals that, in addition to the mean transport, the dominant scale of meridional transport is the largescale (Fig. 3c). The meridional component of the synoptic transport (Fig. 3d) is relatively weak and contributes little to the total northward moisture flux into WA. Meridional transport by climate anomalies are largest near $5^{\circ} \mathrm{S}$, indicating that the source of climate transport flux lies in the South Atlantic Ocean. North of the ITF, the south-to-southeasterly transport usually prevailed. These are dry, hot, and frequently dusty continental air masses crossing the Sahara.

\subsection{Zonal transport}

Figure 4 presents the averaged of each term contributing to the mean zonal flux transport over WA as function of seasonal cycle. The zonal transport is characterized by 
Fig. 3 Seasonal cycle of terms contributing to the vertically integrated mean meridional moisture transport (shading and contours), zonally averaged across $20^{\circ} \mathrm{W}-10^{\circ} \mathrm{E}$. a Total mean transport, $\mathbf{b}$ transport by the mean flow, $\mathbf{c}$ transport by the climate anomalies, and $\mathbf{d}$ transport by synoptic anomalies. Moisture transport is in units of $\mathrm{kg} \mathrm{m}^{-1} \mathrm{~s}^{-1}$. Intervals for contour and shading are $10 \mathrm{~kg} \mathrm{~m}^{-1} \mathrm{~s}^{-1}$, and heavy magenta line indicates the ITF latitude (a) Meridional Flux

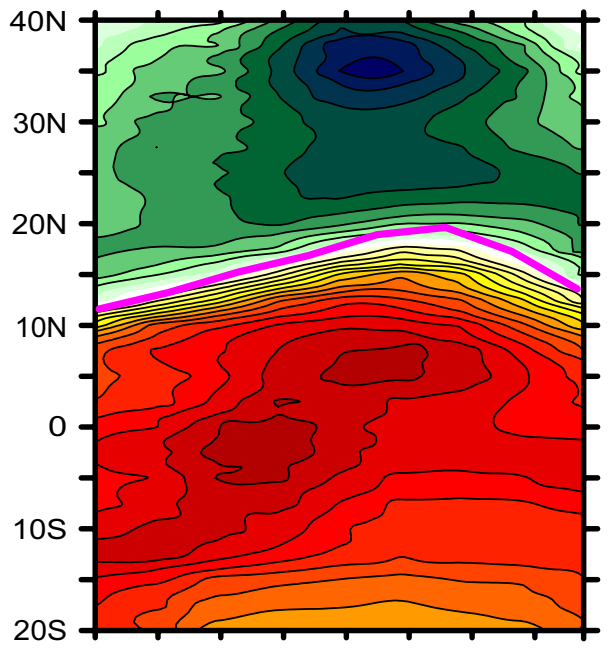

(c) Meridional $\bar{Q}^{C}$

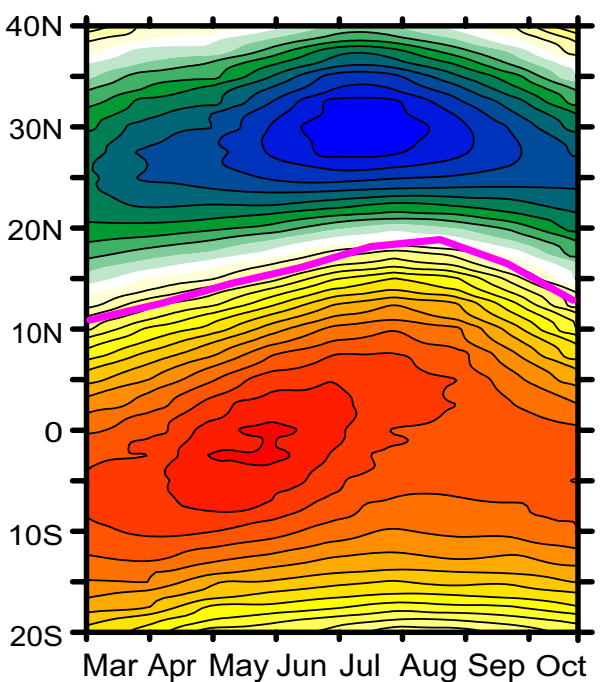

(b) Meridional $\overline{\mathrm{Q}} \mathrm{m}$

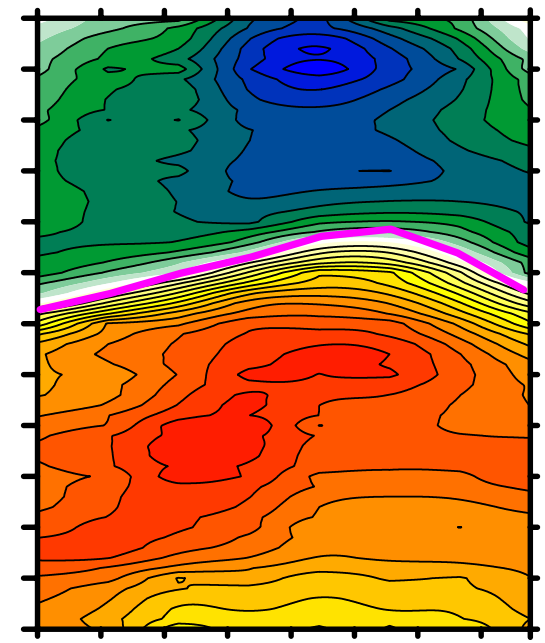

(d) Meridional $\overline{Q^{S}}$

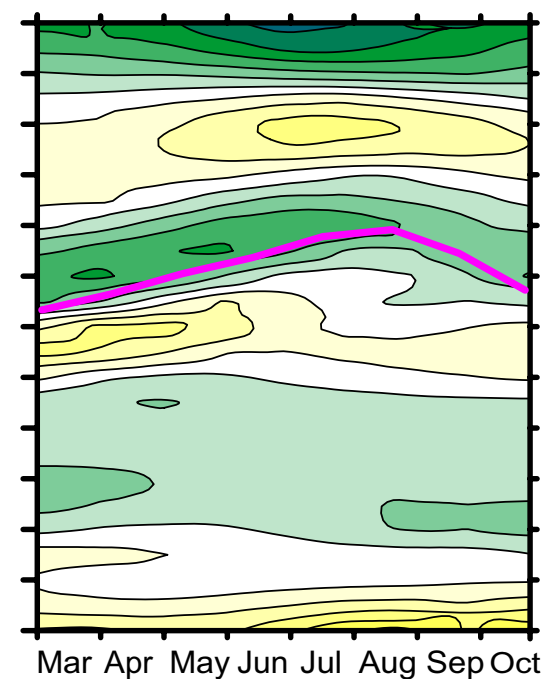

a latitudinal zone of enhanced westward transport over WA banded by regions of eastward transport. The seasonal cycle of the zonal flux transport has a flux maximum in August centered on about $8^{\circ} \mathrm{N}$ (Fig. $4 \mathrm{a}-\mathrm{c}$ ), and associated to the strong westerly flow reported in other studies (e.g., Cadet and Nnoli 1987; Long et al. 2000b; Thorncroft et al. 2011; Pu and Cook 2012; Lélé and al. 2015). The zonal transport by the mean flow also dominates the total transport (Fig. 4b). Next is the large-scale zonal transport that, equivalently, contributes to the total zonal flux (Fig. 4c). The zonal transport by synoptic anomalies (Fig. 4d), although weaker than the mean and the climate-scale transports, presents a considerable degree of east-west detail with centers of eastward transport alternating with centers of westward transport. Unlike the mean and climate anomalies transport of moisture, there is very little similarity between the patterns of the zonal synoptic transport of water flux and the pattern of the total zonal flux transport. Figure $4 \mathrm{~d}$ reveals that the zonal component of the synoptic transport is predominantly westward (negative) over the Sahelian region $\left(10-20^{\circ} \mathrm{N}\right)$. These negative values indicate that synoptic transport are probably responsible for the warm, dry air intrusion that intersects the moist air from the south, and known to be associated with a convection decrease over WA (e.g., Roca et al. 2005; Flaounas et al. 2011). Recent studies (e.g., Rodwell and Hoskins 1996, 
Fig. 4 Same as Fig. 3, but for the vertically integrated zonal moisture transport averaged across $20^{\circ} \mathrm{W}-10^{\circ} \mathrm{E}$

\section{(a) Zonal Flux}



(c) Zonal $\bar{Q}^{\mathrm{C}}$

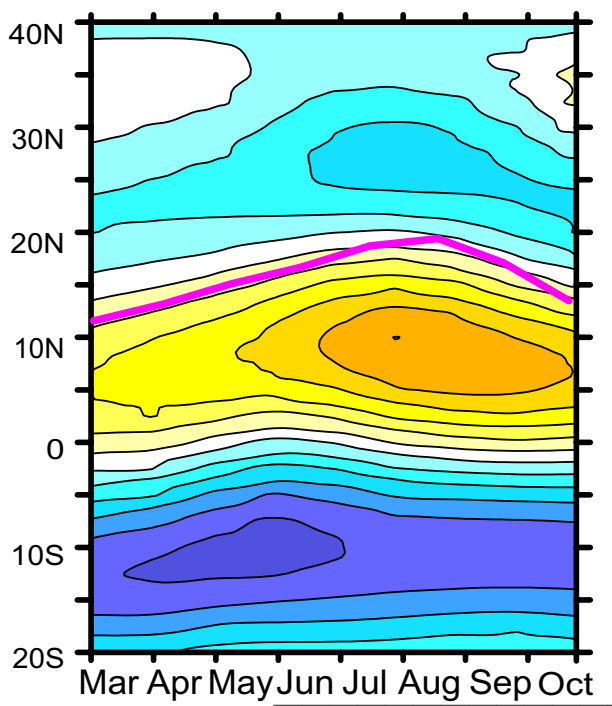

\section{(b) Zonal $\overline{\mathrm{Q}}^{\mathrm{m}}$}

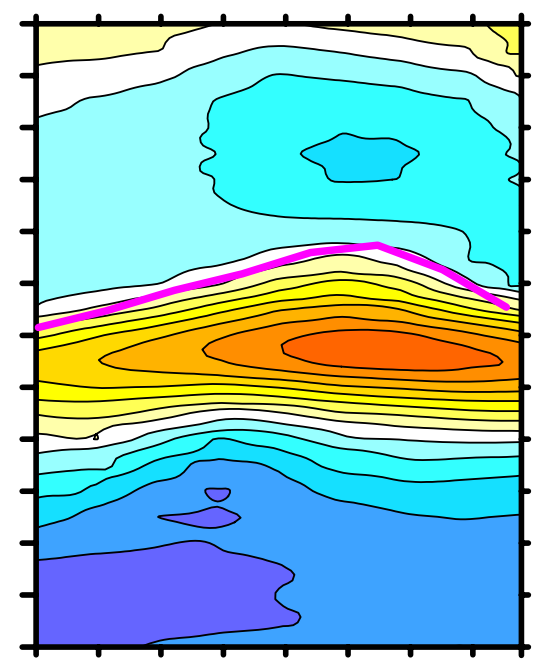

(d) Zonal $\bar{Q} \mathrm{~s}$

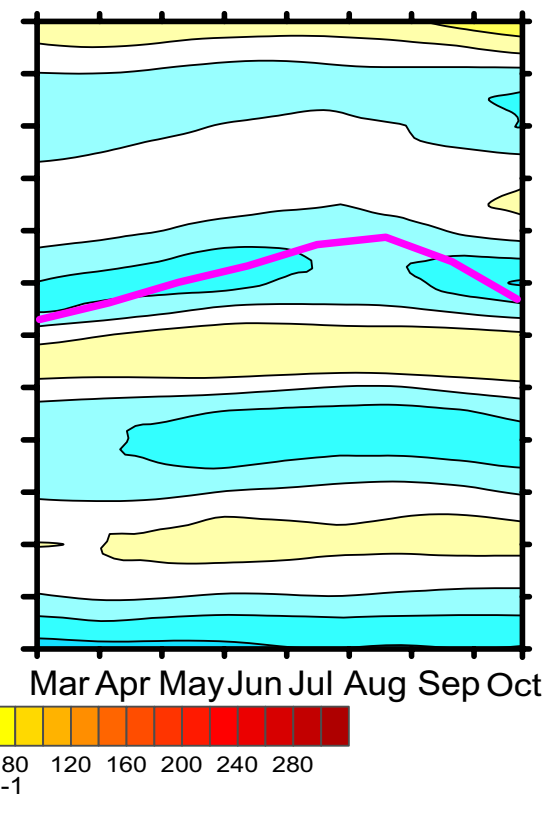

2001) have linked the origin of the dry air to the subsidence over North Africa and East Mediterranean induced by the westward moving Rossby wave forced by convective activity over Northern India.

The strong eastward moisture transport by the mean and the climate anomalies during the core of the Sahelian rainy season (July-September), demonstrates the relationship between the region-scale precipitation variability and moisture fluxes emanating from the west Atlantic into the WA Sahelian zone. This is consistent with previous investigations that relate the zonal moisture transport from the eastern Atlantic and Sahelian rainfall variability (e.g., Pu and Cook 2012; Lélé et al. 2015). Pu and Cook
(2012) analyzed the role of the WAWJ in bringing moisture onto the west coast of Africa during Sahelian wet and dry rainy seasons. They found that during the dry periods, the anomalous moisture transport from the eastern Atlantic was negative and related to a weak WAWJ whereas during the wet period, enhanced eastward moisture transport toward the African land mass was present and related to a strong WAWJ.

\subsection{Annual mean transport}

Figure 5 shows the meridional profiles of the zonaland meridional-moisture transport at all scales for 
Fig. 5 Meridional profiles of the zonal average $\left(20^{\circ} \mathrm{W}-20^{\circ} \mathrm{E}\right)$ of the a meridional and $\mathbf{b}$ zonal moisture fluxes and terms contributing to the their total transport during March-October. Moisture flux is in $\mathrm{kg} \mathrm{m}^{-1} \mathrm{~s}^{-1}$. The dashed horizontal lines indicate the zero meridional and zonal flux, and shading indicates the latitude extent of the West African monsoon domain. A 3-point smoother is applied to the curves

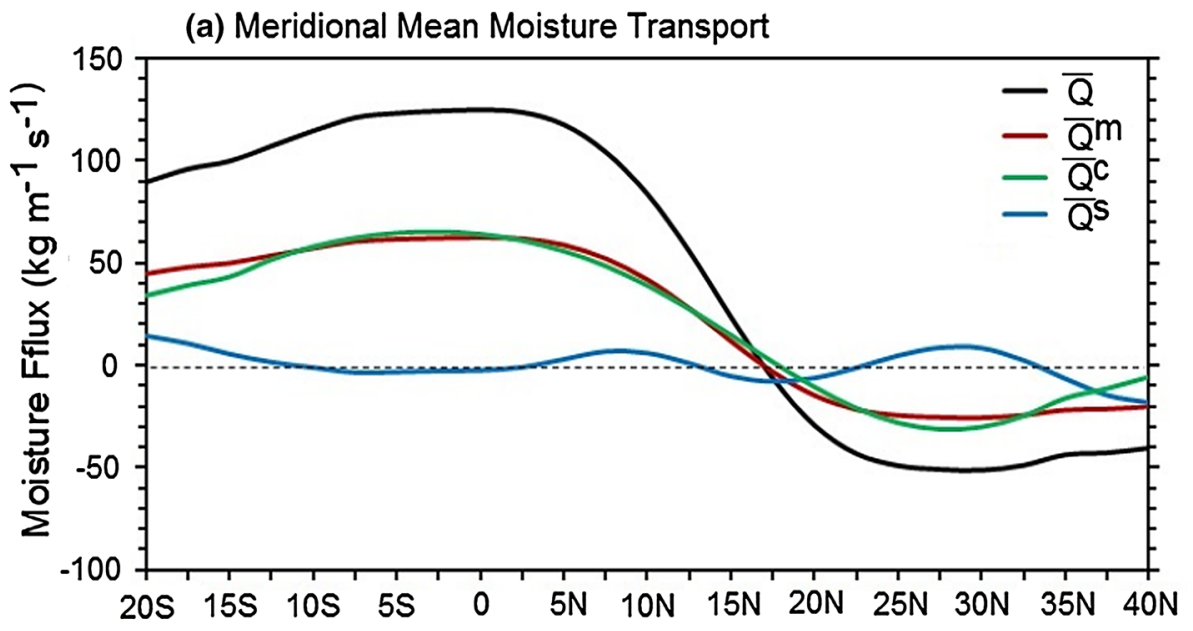

(b) Zonal Mean Moisture Transport

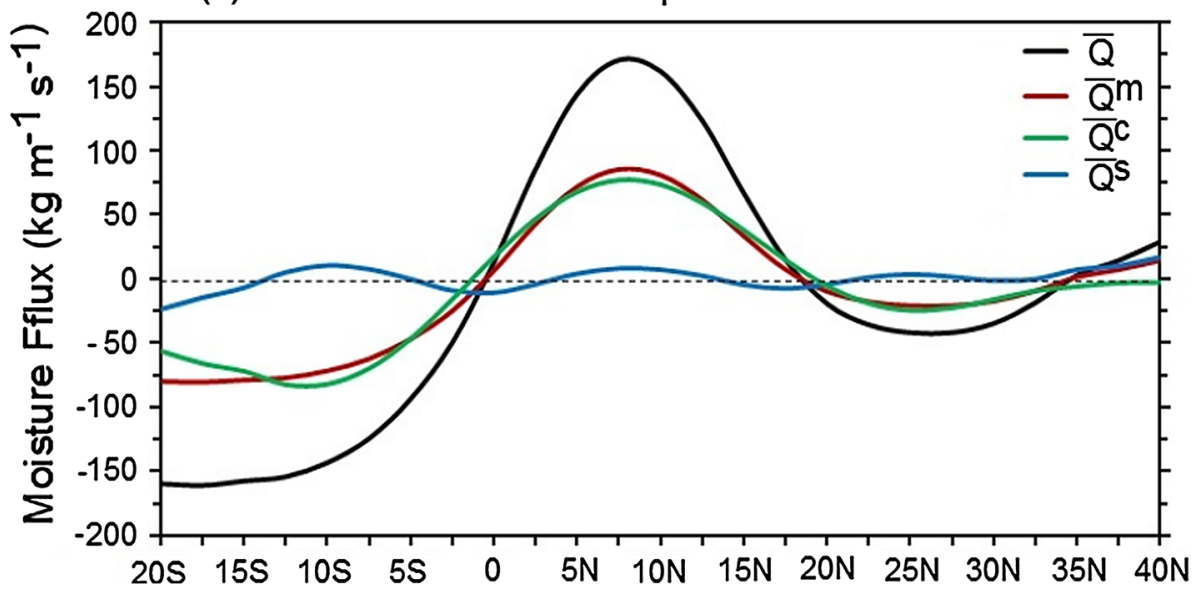

March-October. These profiles summarize the main characteristics of the sub-scale meridional and zonal transports of moisture in WA and the surrounding oceans. The vertical structure of the mean meridional transport is depicted in Fig. 5a. For all the moisture terms, the lowlevel meridional moisture transport is northward between $20^{\circ} \mathrm{S}$ and $20^{\circ} \mathrm{N}$, and southward above $20^{\circ} \mathrm{N}$. The most intense meridional fluxes are observed over the ocean and over the coastal region, with the transport by the mean and climate anomalies dominating the total meridional transport. The confluence zone between the southerlies and the northerlies $\left(20^{\circ} \mathrm{N}\right)$ coincides with the northernmost latitude of the ITF (Lélé and Lamb 2010), and is a rainless zone.

The meridional profiles of the mean zonal flow for all terms is presented in Fig. 5b. The synthesized behavior of the zonal profile indicates easterly flow south of the Equator, westerlies in the vicinity and within the African continent, then easterlies again above $20^{\circ} \mathrm{N}$. The peak total zonal transport is observed near $7.5^{\circ} \mathrm{N}$ and, as for the meridional transport, the transport by the mean and climate anomalies dominate the total transport. It is also important to note that both flux components change sign near $20^{\circ} \mathrm{N}$, indicating the limits of the WAM activities.

\section{Moisture budget and its regulation of West African precipitation}

As described in Eq. 3, the importance of the divergence of water vapor in the atmosphere depends on its relationship with the mean difference of evaporation $\bar{E}$ and precipitation $\bar{P}$ (Peixoto and Oort 1992). The relationships between the low-level atmospheric moisture transport terms and seasonal rainfall over WA were investigated for the 2005 and 2006 monsoon seasons. Note that during 2005, the monsoon season over the Sahelian zone was relatively wet compared with the 2006 season (e.g., Slingo et al. 2008). WAM onset during 2006 was delayed, and as a consequence, the monsoon rainy season was near-normal (e.g., Janicot et al. 2008). The choice of these years, though neither the wettest nor the driest in the study period, was based on the recent AMMA field experiments which provided more reliable observational data for these years. 
Fig. 6 Seasonal mean precipitation and moisture flux convergence terms over the Gulf of Guinea regions during 2005 (left panel) and 2006 (right panel) April-May monsoon seasons. $\mathbf{a}, \mathbf{b}$ are precipitation, $\mathbf{c}-\mathbf{h}$ are moisture flux convergence by the mean flow, the large scale eddies, and the small scale eddies respectively. Precipitation and flux convergence units are in $\mathrm{mm} \mathrm{day}^{-1}$

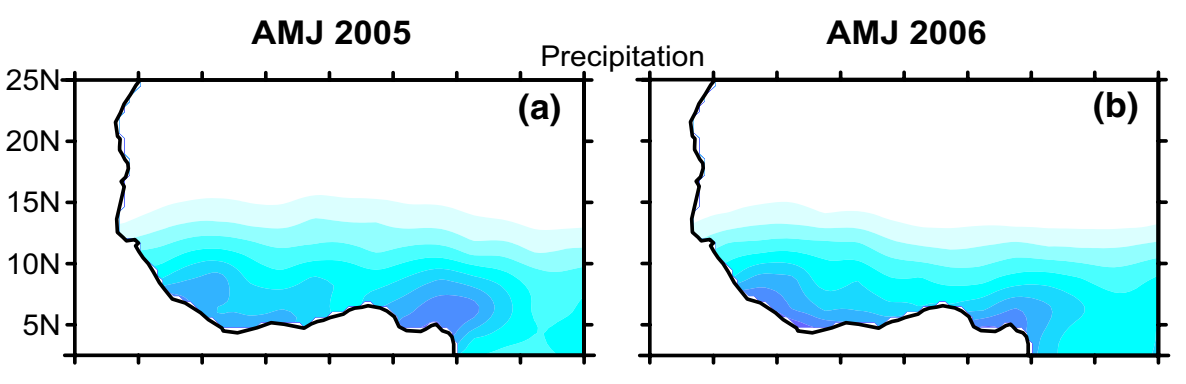

Moisture Flux Convergence (Mean Flow)

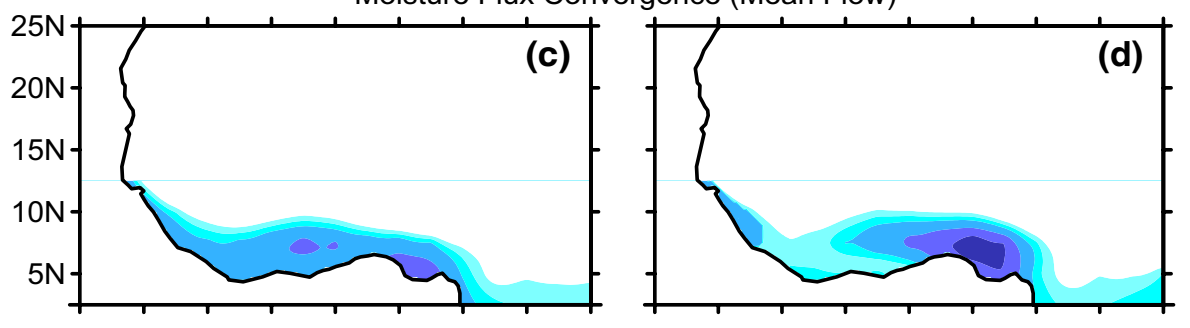

Moisture Flux Convergence (Climate Anomaly)

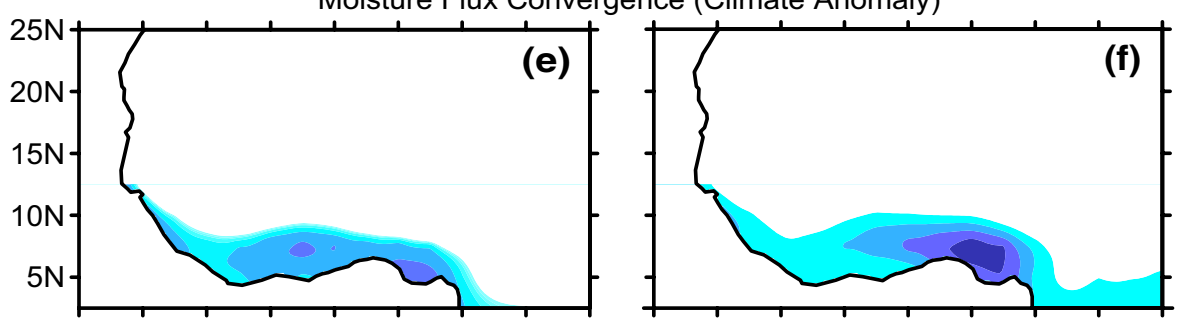

Moisture Flux Convergence (Synoptic Anomaly)

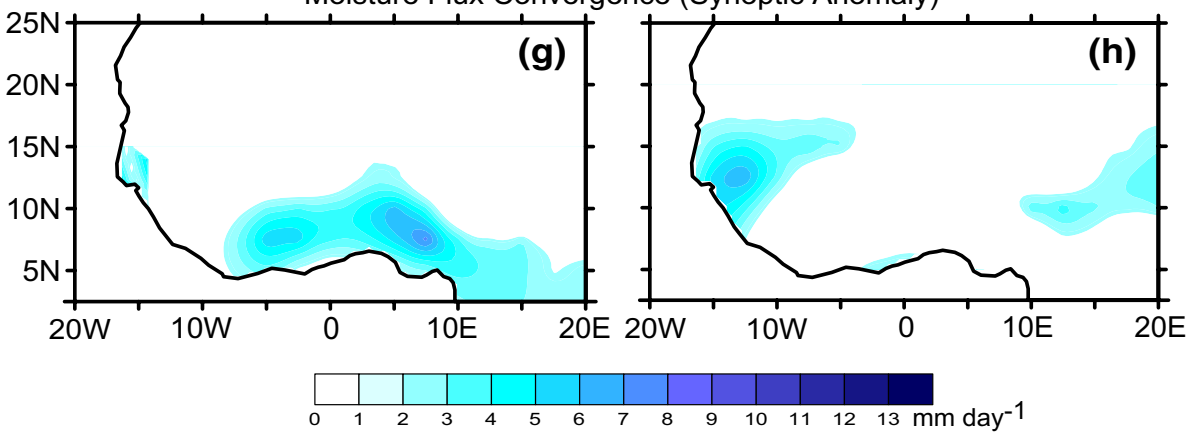

Figure 6 compares the observed rainfall rates during April-June (AMJ) spring season in 2005 and 2006 and the corresponding moisture flux convergence terms, while Fig. 7 compares the same parameters, but for July-September (JAS) monsoon rainy season. During AMJ, rainfall is a maximum near the coastal regions, and extends across the Guinean region, with less precipitation north of $10^{\circ} \mathrm{N}$ in the Sahel (Fig. 6a, b). This precipitation pattern may result from a thermally driven circulation induced by localized land-sea heating contrast along the subtropical coastal areas, and by the cold tongue that develops in late spring over the tropical Atlantic (e.g., Gu and Adler 2004; Joly and Voldoire 2010; Thorncroft et al. 2011). As a manifestation of the first phase of the ITF seasonal cycle, the precipitation belts during the boreal summer abruptly shift northward to the latitudes of about $10^{\circ} \mathrm{N}$, with intense convection across the Sudan-Sahel zone and its diminution over the Guinean coast.

During the 2005 rainy season, the AMJ observed rainfall rates near the Guinea coast (Fig. 6a) is lower $\left(5-7 \mathrm{~mm} \mathrm{day}^{-1}\right)$ than the 2006 observed rainfall rate $\left(7-10 \mathrm{~mm} \mathrm{day}{ }^{-1}\right)$ of the same region (Fig. 6b). However, a comparison of the JAS rainfall reveals that during 2005, rainfall rates were higher over the Sahelian region (Fig. 7a) than during the 2006 season (Fig. 7b). This dipole-type rainfall pattern of wet (dry) Guinea coast and associated dry (wet) Sahel rainfall events has long been recognized and related to sea surface temperature anomalies over the tropical South Atlantic Ocean (e.g., Lamb 1978a). This spatial features of precipitation during the spring and summer 
Fig. 7 Same as Fig. 6, but for period July-August-September over West Africa
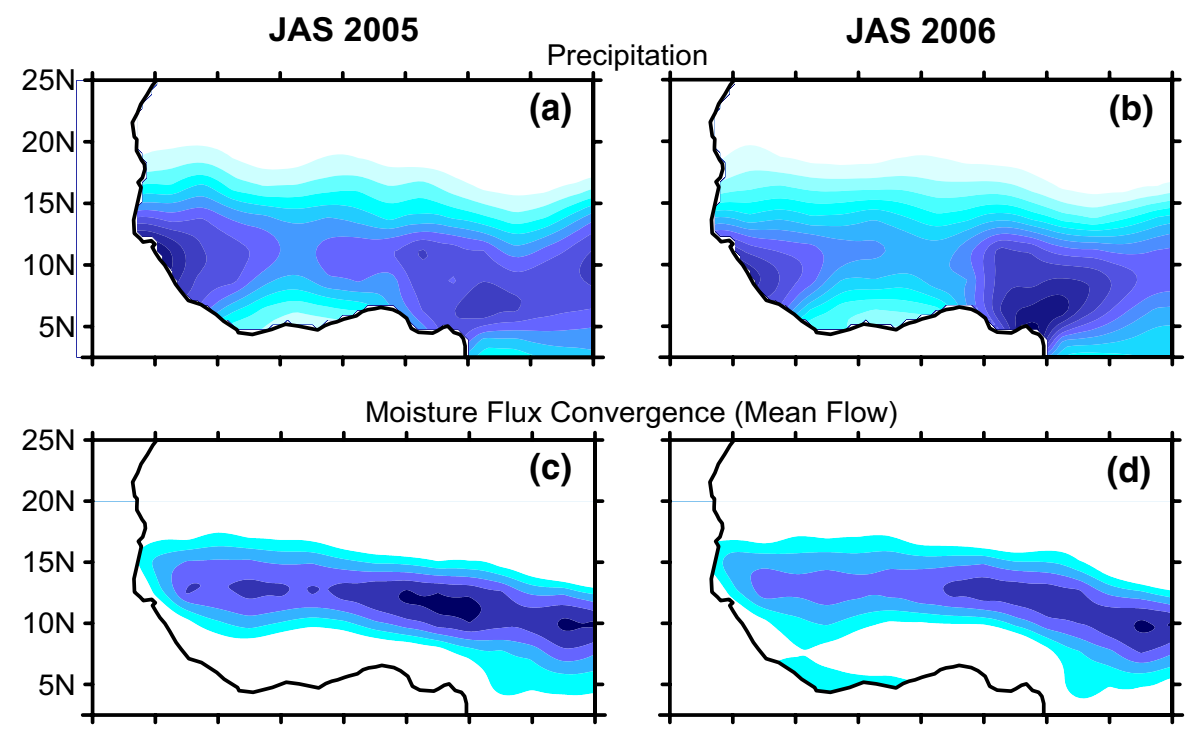

Moisture Flux Convergence (Climate Anomaly)
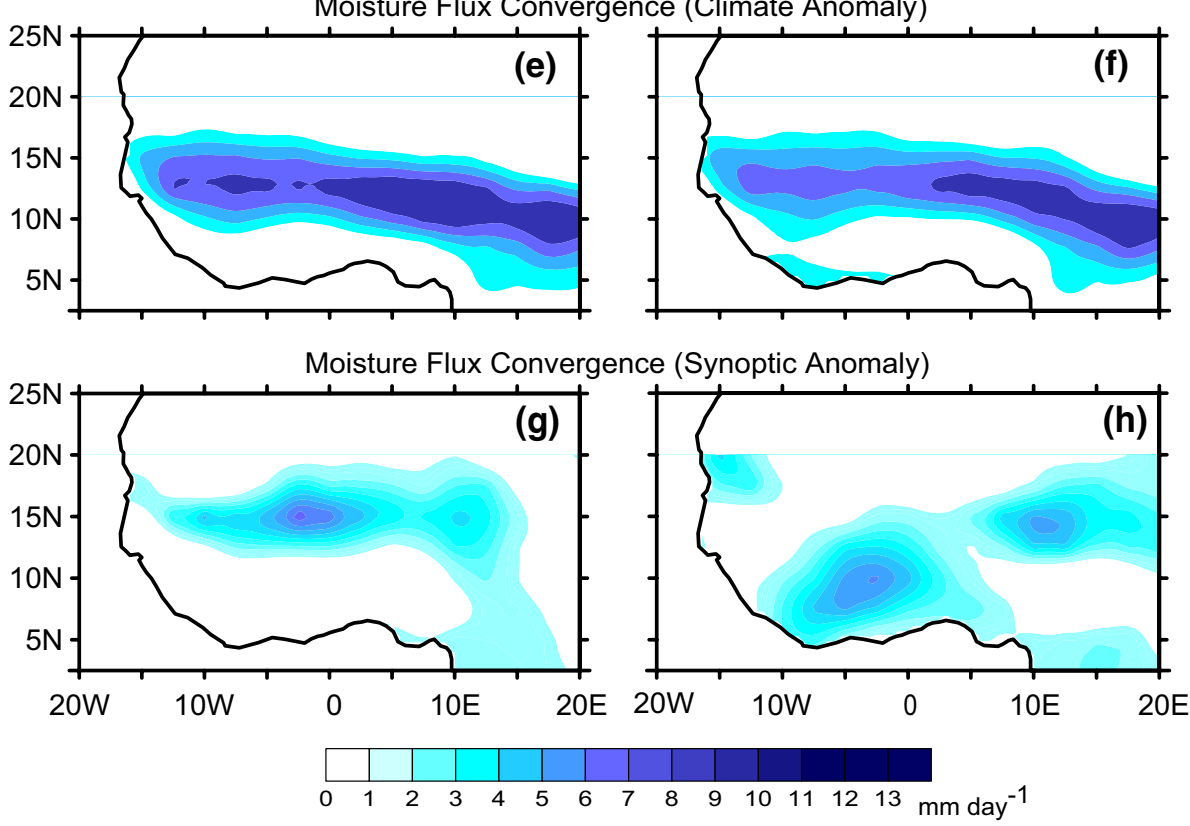

is also reflected in the field of moisture flux convergence. As depicted in Figs. 6c-f, and 7c-f, the convergence by the mean circulation and the climate anomalies are stronger during AMJ 2006 compared to AMJ 2005. This contributes to the abundant AMJ rainfall observed in the Guinea coast during 2006 season. During the JAS season, however, moisture flux convergence by the mean circulation and the climate anomalies are stronger during the 2005 season (Fig. 7c-f) than during the 2006 rainy season (Fig. 7c-f). Consequently, rainfall was abundant over the Sahelian region in 2005, and less in 2006. In both season, the contribution of moisture flux convergence by the climate anomalies is of magnitude almost equal to that of the mean flow, suggesting that precipitation over WA is primarily due to large-scale atmospheric flow features especially during the JAS season.

Synoptic-scale anomalies also contribute to moisture flux convergence and subsequently to WAM precipitation, but this contribution is less than that of the mean and climate circulations. Figures $6 \mathrm{~g}, \mathrm{~h}$, and $7 \mathrm{~g}$, h show the contributions of the synoptic scale moisture flux convergence to the total flux convergence. The largest contributions are located over regions of frequent or intense mesoscale weather phenomena, such as the Fouta Djalon highlands along the coast of Guinea Conakry and Sierra Leone, inland over the Mount Cameroon, and the Adamawa highlands, and on shores of the Gulf of Guinea where land-sea breeze storms have mesoscale organization. During the 


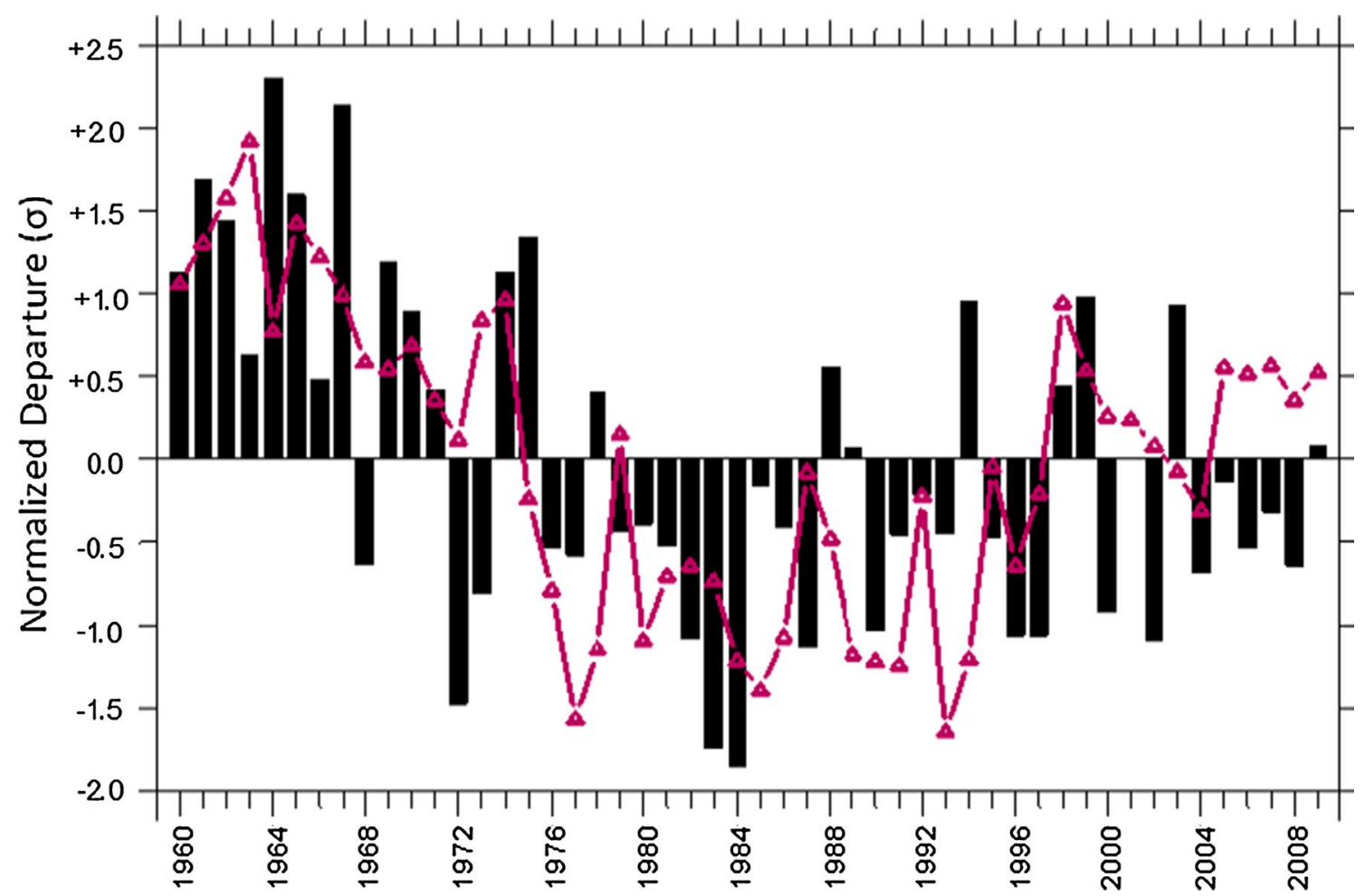

Fig. 8 Time series (1960-2009) of normalized departure ( $\sigma$ ) of JAS precipitation (bars) and moisture convergence (solid line) over Sudan-Sahel zone $\left(17.5^{\circ} \mathrm{W}-10^{\circ} \mathrm{E}, 10-20^{\circ} \mathrm{N}\right)$

anomalously below average rainy season over the Guinean coast in 2005, convergence due to synoptic transport are stronger (Fig. 6e), and contribute significantly to the rainfall amount. However, they are weaker and even suppressed during the 2006 wetter Guinean coast rainy season, where convergence due to climate scale transport dominates the total flux convergence. Conversely, over the Sahelian zone, convergence due to the synoptic transport are stronger and centered over the region during the JAS 2005 wet season, whereas they are weaker and shifted southward during the JAS 2006 lower rainfall season.

\section{Correlation between flux convergence and rainfall}

\subsection{Flux convergence by the mean flow and Sahelian rainfall}

For the analyses of the degree of association between moisture transport terms and precipitation in West Africa Sahelian zone, a time series of observed rainfall averaged was extracted over the domain bounded between $17.5^{\circ} \mathrm{W}$ and $10^{\circ} \mathrm{E}$ longitudes, and $10-20^{\circ} \mathrm{N}$ latitudes. Similarly, a moisture transport index is defined as the area average of the divergence field within the same region. This region is chosen because of the strong interannual rainfall variability that characterizes its summer rainfall season. Figure 8 documents the interannual variation of JAS SudanSahel precipitation and the mean circulation moisture flux convergence during 1960-2009 period. Clearly, the JAS observed rainfall mirrors the flux convergence with a positive correlation $(r=0.60)$, which is significant at the $99 \%$ confidence level according to a two-tailed Student's $t$ test (Wilks 2006, pp.131-135), indicating that rainfall increases (decreases) with enhanced (weakened) moisture flux convergence over the Sudan-Sahel region. When it is area averaged, the mean JAS total moisture flux convergences for the Sahel region during 1960-2009 period amounts to $424 \mathrm{~mm}$. This figure is quantitatively in fairly agreement with the observed $354 \mathrm{~mm}$ for the JAS average total rainfall of the same period.

Figure 8 also indicates that the Sahelian region had experienced wetter condition from the 1960 to $1970 \mathrm{~s}$ and, during those periods, positive anomalies of flux convergence were also observed. The average flux convergence departure relative to the 1960-2009 average is about +1.28 . On the contrary, negative anomalies of flux convergence were observed during the dry periods of the $1970 \mathrm{~s}$ and $1990 \mathrm{~s}$ with an average departure of -0.49 . For the recent periods, often termed the "recovery period" (e.g., Nicholson 2005; Lebel and Ali 2009; Pu and Cook 2012), moisture flux 
Table 1 Correlation coefficients between rainfall and moisture convergence by the mean flow, the large-scale and the small scale anomalies over the Sudan-Sahel zone

\begin{tabular}{llll}
\hline $\begin{array}{l}\text { Sudan-Sahel } \\
\begin{array}{l}\text { average rainfall } \\
\text { index }\end{array}\end{array}$ & $\begin{array}{l}\text { Moisture con- } \\
\text { vergence (mean } \\
\text { flow) }\end{array}$ & $\begin{array}{l}\text { Moisture con- } \\
\text { vergence (cli- } \\
\text { mate anomaly) }\end{array}$ & $\begin{array}{l}\text { Moisture con- } \\
\text { vergence (syn- } \\
\text { optic anomaly) }\end{array}$ \\
\hline$J J$ & & & \\
JJ & $\underline{0.32}$ & $\mathbf{0 . 5 7}$ & 0.03 \\
JA & $\mathbf{0 . 4 5}$ & $\mathbf{0 . 7 9}$ & 0.03 \\
JJA & $\mathbf{0 . 4 9}$ & $\mathbf{0 . 7 9}$ & -0.01 \\
JAS & $\mathbf{0 . 5 2}$ & $\mathbf{0 . 8 4}$ & 0.02 \\
$J J A$ & & & 0.19 \\
JJA & $\mathbf{0 . 6 0}$ & $\mathbf{0 . 8 4}$ & 0.23 \\
JAS & $\mathbf{0 . 6 3}$ & $\mathbf{0 . 8 9}$ & \\
$J A S$ & & & 0.11 \\
JAS & $\mathbf{0 . 6 0}$ & $\mathbf{0 . 8 8}$ & \\
\hline
\end{tabular}

Linear correlation coefficients, all of which are significant at the $1 \%$ (5\%) level are in bold (underline) according to a two-tailed Student's $t$ test (Wilks 2006, 131-135). Time series consist of average of 2 and 3 month values for each year between 1960 and 2009

$J J$ represents the average of rainfall and moisture flux for JuneJuly, $J A$ is July-August, JJA is June-July-August, and JAS is JulyAugust-September

convergence has fluctuated between positive and negative anomalies, together with observed above or below rainfall anomalies. Remarkably, the convergence anomalies during the recovery periods were less than during the $1960 \mathrm{~s}$ wetter years. The average flux convergence departure relative to 1960-2009 is about -0.05 for the recovery period compared with +1.28 for the wetter period. Consequently, rainfall recovery is generally weak and limited in time and space, as suggested by Nicholson (2005) and Lebel and Ali (2009).

\subsection{Moisture flux convergence terms and Sahelian rainfall}

Table 1 shows the correlation coefficients between precipitation and the different terms contributing to the total moisture convergence. Two to three months averages were used to assess the association between the vertically integrated moisture convergence and precipitation. High and statistically significant correlations exceeding the $99 \%$ confidence level are found between the Sahelian rainfall and moisture flux convergence due to the mean flow and to the climate anomalies. These correlations are positive, in agreement with the spatial relationships describe in Sect. 5, and become stronger as the season progresses. Precipitation generally lags the moisture transport. For example, July-August (JA) rainfall is highly correlated with convergence due to the mean and climate circulation of June-July ( $r=0.45 ; 0.79$ ) respectively, which suggests a potential Sudan-Sahel rainfall predictability. No significant correlations were found between Sahelian precipitation and convergence by synoptic transport, which confirms that precipitation over the region is dominated by large-scale anomalies.

The physical and dynamical interpretation of the statistical relations obtained between the moisture flux convergence and rainfall should be supported by assessments of the statistical significance of the correlation coefficients, because they could be biased estimators of the population coefficients. However, the standard $t$ test rests on the assumption that the underlying data are composed of independent samples from their parent populations, which is not always true for atmospheric and other Geophysical data (Wilks 1997). Hence, null hypothesis statistical significance testing in general tells us relatively little of what we need to know and inherently can be misleading (Nicholls 2001). In response to this situation, this study used the Bootstrap techniques (Efron and Tibshirani 1998) to estimate confidence intervals for the correlation coefficients.

Tables 2 and 3 give the $90 \%$ confidence limits for the correlation coefficients, as given by the bootstrap percentiles, the bootstrap- $t$, and the bias-corrected and accelerated $(\mathrm{BCa})$ techniques. It is seen that these three procedures yield results which are similar. These methods provide substantially narrower limits except for when the June-July $(J J)$ moisture flux convergence by the mean flow is used. In that case, the widths of the intervals are relatively wider $(>0.40)$ for all the methods used. Estimates of the correlation coefficients near the lower and upper ends of the confidence interval indicate a strong relationship between moisture convergence by both the mean flow and the climate anomalies and Sudan-Sahel rainfall. However, Table 2 suggests that variance estimates near the lower end of the limits still is distinctly weaker during the beginning of the rainy season $(\mathrm{JJ} ;<10 \%)$ but, even then, it still is moderately strong for the climate anomaly $(\mathrm{JJ} ; 10-53 \%)$. Furthermore, except for the mean flow during $J J$, these confidence limits do not include 0 which suggest the rejection of the null hypothesis and therefore, confirms that the correlation coefficients in Table 1 are indeed statistically significant at the $5 \%$ level of the standard $t$ test.

\section{Conclusions}

Understanding the mechanisms and associated predictability of seasonal-scale rainfall variability over the WAM region requires accurate estimates of the various components of the hydrological cycle. Previous studies of the atmospheric moisture transport over WA have helped to establish the role of the regional circulation in the 
Table 2 Correlation coefficient and approximate bootstrap confidence intervals based on 1000 bootstrap replications for the association between the Sudan-Sahel rainfall and the moisture convergence by the mean flow

\begin{tabular}{lllll}
\hline Rainfall & Mean flow r & $\begin{array}{l}\text { Percentiles } \\
\text { 5th, 95th }\end{array}$ & $\begin{array}{l}\text { Bootstrap-t } \\
\text { 5th, 95th }\end{array}$ & \multicolumn{1}{l}{$\begin{array}{l}\text { BCa } \\
\text { 5th, 95th }\end{array}$} \\
\hline$J J$ & & & & \\
JJ & 0.32 & $0.01,0.59$ & $0.04,0.57$ & $0.02,0.60$ \\
JA & 0.45 & $0.19,0.64$ & $0.19,0.63$ & $0.20,0.65$ \\
JJA & 0.49 & $0.20,0.68$ & $0.20,0.67$ & $0.21,0.68$ \\
JAS & 0.52 & $0.28,0.70$ & $0.26,0.68$ & $0.28,0.71$ \\
JJA & & $0.38,0.75$ & $0.38,0.75$ & $0.39,0.77$ \\
JJA & 0.60 & $0.44,0.77$ & $0.46,0.76$ & $0.45,0.77$ \\
JAS & 0.63 & & & \\
JAS & & $0.39,0.75$ & $0.26,0.68$ & $0.40,0.76$ \\
JAS & 0.60 & & &
\end{tabular}

Table 3 Same as Table 2 but for moisture convergence by the climate anomaly

\begin{tabular}{lllll}
\hline Rainfall & Climate anomaly $\mathrm{r}$ & $\begin{array}{l}\text { Percentiles } \\
\text { 5th, 95th }\end{array}$ & $\begin{array}{l}\text { Bootstrap-t } \\
\text { 5th, 95th }\end{array}$ & $\begin{array}{l}\text { BCa } \\
\text { 5th, 95th }\end{array}$ \\
\hline JJ & & & & \\
JJ & 0.57 & $0.30,0.75$ & $0.31,0.75$ & $0.33,0.78$ \\
JA & 0.79 & $0.61,0.88$ & $0.64,0.88$ & $0.64,0.88$ \\
JJA & 0.79 & $0.61,0.88$ & $0.64,0.88$ & $0.64,0.89$ \\
JAS & 0.84 & $0.71,0.91$ & $0.73,0.91$ & $0.72,0.91$ \\
JJA & & & & \\
JJA & 0.84 & $0.69,0.91$ & $0.71,0.91$ & $0.72,0.92$ \\
JAS & 0.89 & $0.79,0.94$ & $0.81,0.93$ & $0.80,0.94$ \\
JAS & & & & \\
JAS & 0.88 & $0.78,0.93$ & $0.80,0.93$ & $0.79,0.93$ \\
\hline
\end{tabular}

hydrological cycle through the vertically integrated lowlevel atmospheric moisture flux. (e.g., Lamb 1978; Cadet and Nnoli 1987; Gong and Eltahir 1996; Long et al. 2000; Lélé et al. 2015). These analyses have indicated that the WAM is characterized by a seasonal reversal of the prevailing lower tropospheric wind, which in the boreal summer has a southwesterly (onshore) orientation. The resulting transport of moist air across the Gulf of Guinea coast helps initiate and sustain deep convection over the region, between June and September. It is also shown that the interannual variation of boreal rainfall in the WA Sudan-Sahel region is reflected in the latitude position of the ITF which, in turn, is associated with the low-level moisture transport from the tropical Atlantic. The Mediterranean basin, local evaporation, and evaporation in areas east of the WAM domain have also been identified as sources of water vapor (e.g., Gong and Eltahir 1996; Fontaine et al. 2003; Nieto et al. 2006). However, these studies have used the averages of moisture flux over particular time interval such as monthly, seasonal, or yearly averages even though, on a regional basis, the anomalies occur both in time and space.

In this study, the contributions of both the synoptic and climate time scale anomalies of moisture transport are investigated over the WAM region. An application of wavelet analysis to the vertically integrated low-level moisture flux shows a rich spectrum of variability, with associated well-defined synoptic- and larger-scale circulation features that evolve over a range of periods. In particular, the flux variability is mostly dominated by spectral peaks centered on periods of 15 days and 50 days. These time-scales are consistent with those found in other studies (e.g., Janicot and Sultan 2001; Grodsky and Carton 2001; Sultan et al. 2003; Lavaysse et al. 2006; Maloney and Shaman 2008). The low-level moisture transport was partitioned into three time-scales consisting of: (i) the transport by the mean circulation, (ii) the transport by the synoptic (high frequency) anomalies, corresponding of time-scale less than 10 day, and (iii) the climate-scale (low frequency) transport which, consists of climate anomalies with time-scale greater than 10 days. The relative contribution of each scale of transport to the seasonal cycle of summer monsoon flux divergence and associated rainfall is assessed.

Analysis of the seasonal cycle of the mean vertically integrated atmospheric moisture budget using 50 years of NCEP-NCAR reanalysis data reveals that the climate and synoptic anomalies play a significant role in the low-level atmospheric moisture budget in WA. Transport by the mean circulation from the Gulf of Guinea to the Sahel exceeds $200 \mathrm{~kg} \mathrm{~m}^{-1} \mathrm{~s}^{-1}$ and its divergence exceeds $3 \mathrm{~mm}_{\text {day }}{ }^{-1}$ during June-September, and are the major contributors to precipitation in WA (e.g., Lele et al. 2015). Transport by the climate anomalies of about $120 \mathrm{~kg} \mathrm{~m}^{-1} \mathrm{~s}^{-1}$ and its divergence of approximately $2 \mathrm{~mm}$ day $^{-1}$ also contribute significantly. Contribution of synoptic-scale anomalies is substantial only over the higher topographic areas. This suggests that atmospheric moisture transport mechanism is part of the large-scale circulation changes in response to global SST variations, which provide forcing of Sahelian interannual-to-decadal rainfall variability (e.g., Lamb 1978a, b; Hastenrath 1990; Ward 1998; Giannini et al. 2003).

The breakdown of the meridional moisture transport field into the component due by the time-mean flow and to components due by the climate and synoptic circulations, reveal a predominantly poleward transport throughout the monsoon season. For both the Guinea coast and the Sahel region, the meridional transport by the mean flow and climate anomalies are the largest contributors to the net meridional low-level moisture transport. Similarly, the zonal transport field due by the mean flow and the climate anomalies dominate the total zonal transport, and contribute to moisture flux convergence 
over the Guinean coast and the Sahelian region. The zonal transport by the synoptic time-scale on the other hand is positive over the Guiean coast and negative over the Sahelian region. This suggest that synoptic transport is a key moisture source for the Gulf of Guinea region while it transport moisture zonally out of the Sahelian region.

Comparison of the seasonal cycles of moisture flux convergence during the 2005 and 2006 monsoon season highlights the contribution of each moisture transport terms to the total moisture flux convergence. The convergence due to large-scale anomalies is seen to be greater than the flux convergence due to the synoptic transport, and contribute the most to the total moisture convergence along the coastal regions during the spring season (April-June), and over the Sahelian region during the summer (July-September) season. The magnitude of moisture convergence by the climate anomalies is almost equal to that of the mean flow suggesting that precipitation over WA is primarily due to large-scale atmospheric features especially during the July-August season. Synoptic-scale moisture convergence, however, are located over regions of frequent or intense mesoscale weather phenomenon, such as the orographic areas and on the shores of the Gulf of Guinea where land-sea breeze storms have mesoscale organization. A positive and statistically significant correlations exceeding the $99 \%$ confidence level was found between moisture flux convergence due to the mean flow and Sahelian rainfall (e.g., JAS, $r=+0.63$ ), and flux convergence due to climate anomalies and Sahelian rainfall (e.g., $J A S, r=+0.89)$. This supports the hypothesis that rainfall increases (decreases) with the enhanced (diminished) anomalously moisture convergence over the Sudan-Sahel region. However, no significant correlations were found between Sahelian precipitation and moisture flux convergence due to synoptic transport, which confirms that precipitation over the region is dominated by large-scale anomalies.

Acknowledgments The research was supported by the Cooperative Institute for Mesoscale Meteorological Studies (CIMMS), The University of Oklahoma, Norman, Oklahoma, USA. The constructive suggestions of anonymous reviewers sharpened the manuscript.Open Access This article is distributed under the terms of the Creative Commons Attribution 4.0 International License (http://creativecommons.org/licenses/by/4.0/), which permits unrestricted use, distribution, and reproduction in any medium, provided you give appropriate credit to the original author(s) and the source, provide a link to the Creative Commons license, and indicate if changes were made.

\section{Appendix}

\section{Method use for scale decomposition of moisture budget}

The vertically integrated moisture transport $\vec{Q}$ is obtained by integrating over the depth of the atmosphere. The moisture budget indicates that precipitation, evaporation, and net moisture transport into and out of an atmospheric column through its lateral boundary are in balance at the seasonal time-scale (Brubaker et al. 1993). Following Peixoto and Oort (1992), the atmospheric water budget in pressure coordinates is expressed as follows:

$\frac{\partial W}{\partial t}+\nabla \cdot Q=E-P$

In Eq. (5), $W$ is precipitable water, $E$ is evaporation from the surface, $P$ is precipitation, and $\nabla \cdot \boldsymbol{Q}$ is the divergence field of moisture flux, which represents the net moisture transport. From a climatological perspective, the long-term accumulation of precipitable water in the atmosphere is negligible $(\partial W / \partial t=0)$ and moisture budget is a balance between moisture flux divergence and the water source/ sink. Thus, Eq. (5) yield:

$\nabla \cdot Q=E-P$

The vertically integrated moisture flux in Eq. (6) is:

$\boldsymbol{Q}=\frac{1}{g} \int_{p_{t}}^{p_{s}} q \boldsymbol{V} d p=q \boldsymbol{V} p$

Where $q$ is specific humidity, $p$ is surface pressure, $\boldsymbol{V}$ is the horizontal wind vector, and the brackets indicate the vertical integral in pressure coordinates. We define $q=\bar{q}+q^{c}+q^{s}$ and similarly for all other variables, where overbars indicate the seasonally varying climatological mean and superscripts indicate climate (c) time-scale or low frequency (LF) and synoptic (s) time-scale anomalies. Anomalies were defined by removing each variable's annual cycle. Climate time-scale or LF anomalies are determined from a wavelet filter that passes periods greater than 10 days, and synoptic anomalies are the residuals representing periods less than 10 days; this frequency cutoff was chosen since it is common to a great many studies of LF variability dating back to Blackmon et al. (1977). Applying these definitions to (2), we obtain the following seasonally varying mean moisture budget:

$\nabla \cdot \bar{Q}=\bar{E}-\bar{P}$

where the mean moisture transport is:

$$
\begin{aligned}
\overline{\boldsymbol{Q}}= & \overline{P \boldsymbol{V} q}=\bar{P} \overline{\boldsymbol{V}} \bar{q}+\left\{\bar{P} \overline{\boldsymbol{V}^{c} q^{c}}+\bar{q} \overline{\boldsymbol{V}^{c} P^{c}}+\overline{\boldsymbol{V}} \overline{q^{c} P^{c}}+\overline{\boldsymbol{V}^{c} q^{c} P^{c}}\right\} \\
& +\left\{\bar{P} \overline{\boldsymbol{V}^{s} q^{s}}+\bar{q} \overline{\boldsymbol{V}^{s} P^{s}}+\overline{\boldsymbol{V}} \bar{q}^{s} P^{s}+\overline{\boldsymbol{V}^{s} q^{s} P^{s}}\right\}
\end{aligned}
$$

The last three terms that depend on $P$ anomalies within each curly bracket in Eq. (9) are negligible, but they have been included in the computation of $\overline{\boldsymbol{Q}}^{c}$ and $\overline{\boldsymbol{Q}}^{s}$. Thus, the mean moisture transport Eq. (9) yield:

$\overline{\boldsymbol{Q}}=\overline{\boldsymbol{Q}}^{m}+\overline{\boldsymbol{Q}}^{c}+\overline{\boldsymbol{Q}}^{s}$ 
where $\overline{\boldsymbol{Q}}^{m}=\bar{P} \overline{\boldsymbol{V}} \bar{q}$ denotes the "transport by the mean" $\overline{\boldsymbol{Q}}^{c}=\bar{P} \overline{\boldsymbol{V}^{c} q^{c}}$ "transport by climate anomaly" or "low frequency transport", and $\boldsymbol{Q}^{s}=\bar{P} \overline{V^{s} q^{s}}$ "synoptic transport".

\section{References}

Agustí-Panareda A, Beljaars A, Cardinali C, Genkova I, Thorncroft C (2010) Impacts of Assimilating AMMA Soundings on ECMWF Analyses and Forecasts. Weather Forecasting 25:1142-1160. doi $: 10.1175 / 2010$ WAF2222370.1

Bell MA, Lamb PJ (2006) Integration of Weather System Variability to Multidecadal Regional Climate Change: The West African Sudan-Sahel Zone, 1951-98. J Clim 19:5343-5365

Biasutti M, Held IM, Sobel AH, Giannini A (2008) SST Forcings and Sahel Rainfall Variability in Simulations of the Twentieth and Twenty-First Centuries. J Clim 21:3471-3486

Bielli S, Roca R (2009) Scale decomposition of atmospheric water budget over West Africa during the monsoon 2006 from NCEP/ GFS analyses. Clim Dyn 35:143-157

Bock O, Nuret M (2009) Verification of NWP Model Analyses and Radiosonde Humidity Data with GPS Precipitable Water Vapor Estimates during AMMA. Weather Forecasting 24:1085-1101. doi:10.1175/2009WAF2222239.1

Bock O, Guichard F, Agusti-Panareda A, Beljaars A, Boone A, Meynadier R, Nuret M, Redelsperger J-L, Roucou P (2011) The large scale water cycle of the West African Monsoon. Atmos Sci Lett 12:51-57. doi:10.1002/as1.288

Burpee RW (1975) Some features of synoptic-scale waves based on compositing analysis of GATE data. Mon Wea Rev 103:921-925

Cadet DL, Nnoli O (1987) Water vapour transport over Africa and the Atlantic Ocean during summer 1979. Q J. R Meteorl Soc 113:581-602

Caminade C, Terray L (2010) Twentieth century Sahel rainfall variability as simulated by the ARPEGE AGCM, and future changes. Clim Dyn 35(1):75-94. doi:10.1007/s00382-009-0545-4

Clark DB, Xue Y, Harding RJ, Valdes PJ (2001) Modeling the impact of land surface degradation on the climate of tropical North Africa. J Clim 14:1802-1822

Cook KH (1999) Generation of African Easterly Jet and Its Role in Determining West African Precipitation. J Clim 12:1165-1184

Cook KH, Vizy EK (2006) Coupled model simulations of the West African monsoon system: Twentieth- and Twenty-first-century simulations. J Clim 19:3681-3703

Couvreux F, Guichard F, Bock O, Campistron B, Lafore J-P, Redelsperger J-L (2010) Synoptic variability of the monsoon flux over West Africa prior to the onset. Q J R Meteor Soc 136:159-173. doi:10.1002/qj.473

Diedhiou A, Janicot S, Viltard A (1999) Easterly wave regimes and associated convection over West Africa and tropical Atlantic Ocean: Results from NCEP/NCAR and ECMWF reanalysis. Clim Dyn 11:795-822

Druyan LM, Koster RJ (1989) Sources of Sahel precipitation for simulated drought and rainy seasons. J Clim 2:1438-1446

Flaounas E, Janicot S, Roca R, Bastin S, Mohino E (2011) The role of the Indian monsoon onset on the African monsoon onset: observations and AGCM nudged simulations. Clim Dyn. doi:10.1007/ s00382-011-1045-X

Fontaine B, Roucou P, Trzaska S (2003) Atmospheric water cycle and moisture fluxes in the West African monsoon: mean annual cycles and relationship using NCEP/NCAR reanalysis. Geophys Res Lett. doi:10.1029/2002GL015834

Giannini A, Saravanan R, Chang P (2003) Oceanic forcing of Sahel rainfall on interannual to interdecadal time scales. Science. doi:10.1126/science. 1089357
Gong C, Eltahir E (1996) Sources of moisture for rainfall in West Africa. Water Resour Res 32:3115-3121

Grams CM, Jones SC, Marsham JH, Parker DJ, Haywood JM, Heuveline V (2010) The Atlantic Inflow to the Saharan heat low: observations and modelling. Q J R Meteor Soc 136(SI1):125-140. doi:10.1002/qj.429

Grist JP, Nicholson SE (2001) A study of the dynamic factors influencing the interannual variability of rainfall in the West African Sahel. J Clim 14:1337-1359

Grodsky SA, Carton JA (2001) Coupled land/atmosphere interactions in the West African monsoon. Geophys Res Lett 28:1503-1506

Gu G, Adler RF (2004) Seasonal Evolution and Variability Associated with the West African Monsoon System. J Clim 17:3364-3377

Hastenrath S (1990) The Relationship of Highly Reflective Clouds to Tropical Climate Anomalies. J Clim 3:353-365

Hodges KI, Hoskins BJ, Boyle J, Thorncroft C (2003) A comparison of recent reanalysis datasets using objective feature tracking: storm tracks and tropical easterly waves. Mon Wea Rev 131:2012-2037

Hoerling M, Hurrell J, Eischeid J, Phillips A (2006) Detection and Attribution of Twentieth-Century Northern and Southern African Rainfall Change. J Clim 19:3989-4008

Hoerling M, Eisheid J, Perlwitz J (2010) Regional precipitation trends: distinguishing natural variability from anthropogenic forcing. J Clim 23:2131-2145

Janicot $\mathrm{S}$ et al (2008) Large-scale overview of the summer monsoon over West Africa during the AMMA field experiment in 2006. Ann Geophys 26:2569-2595

Janicot S, Sultan B (2001) Intra-seasonal modulation of convection in the West African monsoon. Geophys Res Lett 28:523-526

Joly M, Voldoire A (2010) Role of the Gulf of Guinea in the interannual variability of the West African monsoon: what do we learn from CMIP3 coupled simulations? Int J Climatol 30:1843-1856

Kalnay E et al (1996) The NCEP/NCAR 40-Year Reanalysis Project. Bulletin Am Meteor Soc 77:437-471

Kidson JW (1977) African rainfall and its relation to the upper air circulation. Q J R Meteor Soc 103:441-456

Kinter JL III, Fennessy MJ, Krishnamurthy V, Marx L (2004) An evaluation of the apparent interdecadal shift in the tropical divergent circulation in the NCEP-NCAR reanalysis. J Clim 17:349-361

Lamb PJ (1978) Case studies of tropical Atlantic surface circulation patterns during recent sub-Saharan weather anomalies: 1967 and 1968. Mon Wea Rev 106:482-491

Lamb PJ (1983) West African water vapor variations between recent contrasting sub-Saharan rainy seasons. Tellus 35A:198-212

Lau KM, Shen SSP, Kim KM, Wang H (2006) A multimodel study of the twentieth-century simulations of Sahel drought from the 1970 s to 1990s. J Geophys Res 111:D07111. doi:10.1029/200 5JD006281

Lavaysse C, Diedhiou A, Laurent H, Lebel T (2006) African easterly waves and convective activity in wet and dry sequences of the west African monsoon. Clim Dyn 27:319-332

Le Barbé L, Lebel T (1997) Rainfall climatology in the HARPEXSahel region during the years 1950-1990. J Hydrol 188-189:43-73

Lebel T, Ali A (2009) Recent trends in the Central and Western Sahel rainfall regime (1990-2007). J Hydrol 375:52-64

Lélé IM, Lamb PJ (2010) Variability of the Intertropical Front (ITF) and Rainfall over the West African Sudan-Sahel Zone. J Clim 23:3984-4004

Lélé IM, Leslie L, Lamb P (2015) Analysis of Low-level Atmospheric Moisture Transport Associated with the West African Monsoon. J Clim. doi:10.1175/JCLI-D-14-00746.1

Long M, Entekhabi D, Nicholson SE (2000a) Interannual variability in rainfall, water vapor flux, and vertical motion over West Africa. J Clim 13:3827-3841 
Long M, Entekhabi D, Nicholson SE (2000b) Interannual variability in rainfall, water vapor flux, and vertical motion over West Africa. J Clim 13:3827-3841. doi:10.1175/1520-0442(2000)013,3827:IVI RWV.2.0.CO;2

Loschnigg J, Webster PJ (2000) A Coupled Ocean-Atmosphere System of SST Modulation for the Indian Ocean. J Clim 13:3342-3360

Maloney ED, Shaman J (2008) Intraseasonal variability of the West African monsoon and Atlantic ITCZ. J Clim 21:2898-2918

Martin ER, Thorncroft C (2014) Sahel rainfall in multimodel CMIP5 decadal hindcasts. Geophys Res Lett 41:2169-2175. doi:10.100 2/2014GL059338

Mera R, Laing AG, Semenzzi F (2014) Mousture Variability and Multiscale Interactions during spring in West Africa. Mon Wea Rev 142:3178-3198

Meynadier R, Bock O, Guichard F, Boone A, Roucou P, Redelsperger J-L (2010a) West African Monsoon water cycle: 1. A hybrid water budget dataset. J Geophys Res 115:D19106. doi:10.1029/ 2010JD013917

Meynadier R, Bock O, Gervois S, Guichard F, Redelsperger J-L, Agustí-Panareda A, Beljaars A (2010b) West African Monsoon water cycle: 2. Assessment of numerical weather prediction water budgets. J Geophys Res 115:D19107. doi:10.1029/201 0JD013919

Mo KC, Higgins RW (1996) Large-scale atmospheric moisture transport as evaluated in the NCEP/NCAR and the NASA/DAO reanalyses. J Clim 9:1531-1545

Mo KC, Chelliah M, Carrera ML, Higgins RW, Ebisuzaki W (2005) Atmospheric moisture transport over the United States and Mexico as evaluated in the NCEP regional reanalysis. J Hydrometeorol 6(5):710-728

Newman M, Kiladis GN, Weickmann KM, Ralph FM, Sardeshmukh PD (2012) Relative Contributions of Synoptic and Low-Frequency Eddies to Time-Mean Atmospheric Moisture Transport, Including the Role of Atmospheric Rivers. J Clim 25:7341-7361

Nicholson S (2005) On the question of the "recovery" of the rains in the West African Sahel. J Arid Environ 63:615-641

Nicholson SE (2008) The intensity, location and structure of the tropical rainbelt over West Africa as factors in interannual variability. Int J Climatol 28:1775-1785

Nicholson S, Grist JP (2003) On the seasonal evolution of atmospheric circulation over West Africa and equatorial Africa. J Clim 16:1013-1030

Nicholson S, Webster PJ (2007) A physical basis for the interannual variability of rainfall in the Sahel. Q J R Meteor Soc 133:2065-2084

Nieto R, Gimeno L, Trigo RM (2006) A Lagrangian identification of major sources of Sahel moisture. Geophys Res Lett. doi:10.1029 /2006GL027232

Peixoto JP, Oort AH (1992) Physics of climate. Springer, New York

Poccard I, Janicot S, Camberlin P (2000) Comparison of rainfall structures between NCEP/NCAR reanalysis and observed data over tropical Africa. Clim Dyn 16:897-915

$\mathrm{Pu}$ B, Cook KH (2012) Role of the West African westerly jet in Sahel rainfall variations. J Clim 25:2880-2896

Redelsperger J-L, Thorncroft CD, Diedhiou A, Lebel T, Parker DJ, J Polcher (2006) African monsoon multidisciplinary analysis: an international research project and field campaign. Bull Am Meteorol Soc 87(12): 1739-1746

Roca R, Lafore JP, Piriou C, Redelsperger JL (2005) Extratropical dry-air intrusions into the West African monsoon midtroposphere: an important factor for the convective activity over the Sahel. J Atmos Sci 62:390-407

Rodwell MJ, Hoskins BJ (1996) Monsoons and the dynamics of deserts. Q J R Meteorol Soc 122:1385-1404
Schneider T, Smith KL, O'Gorman PA, Walker CC (2006) A climatology of tropospheric zonal-mean water vapor fields and fluxes in isentropic coordinates. J Clim 19:5918-5933

Slingo A et al (2008) Overview of observations from the RADAGAST experiment in Niamey, Niger: Meteorology and thermodynamic variables. J Geophys Res. doi:10.1029/2008JD009909

Sultan B, Janicot S, Diedhiou A (2003) The West African Monsoon Dynamics. Part I: Documentation of Intraseasonal Variability. J Clim 16(21):3389-3406

Thorncroft CD, Nguyen H, Zhang C, Peyrillé P (2011) Annual cycle of the West African monsoon: regional circulations and associated water vapour transport. Q J R Meteor Soc 137:129-147. doi:10.1002/qj.728

Trenberth KE, Smith L, Qian T, Dai A, Fasullo JT (2007) Estimates of the global water budget and its annual cycle using observational and model data. J Hydrometeorol 8:758-769

Trenberth KE, Fasullo JT, Mackaro J (2011) Atmospheric moisture transports from ocean to land and global energy flows in reanalyses. J Clim 24:4907-4924

Trewartha GT, Horn LH 1980 An introduction to climate. Fifth Edition. McGraw-Hill, Inc, pp 416

Viltard A, Oubuih J, de Félice E, Laurent H (1998) Rainfall and the 6-9 day wave-like disturbance in West- Africa during summer 1989. Meteorol Atmos Phys 66:229-234

Wang M, Paegle J (1996) Impact of analysis uncertainty upon regional atmospheric moisture flux. J Geophys Res: Atmos 101 (D3):7291-7303

Ward MN (1998) Diagnosis and short-lead time prediction of summer rainfall in tropical North Africa at interannual and multidecadal timescales. J Clim 11:3167-3191

Webster PJ (1987) The Elementary Monsoon. In: Fein JS, Stephens PL (eds) Monsoons. Wiley, New York, pp 3-32

Wilks DS 2006: Statistical Methods in the Atmospheric Sciences (Second Edition), Academic Press pp 627

Xue Y (1997) Biophere feedback on regional climate in tropical North Africa. Q J R Meteorol Soc 123:1483-1515

Xue Y, Shukla J (1993) The Influence of Land Surface Properties on Sahel Climate. Part 1: Desertification. J Clim 6:2232-2245

Xue YK et al (2010) Intercomparison and analyses of the climatology of the West African monsoon in the West African Monsoon Modeling and Evaluation project (WAMME) first model intercomparison experiment. Clim Dyn 35:3-27. doi:10.1007/ s00382-010-0778-2

Xue YF, De Sales W, Lau WK-M, Boone A, Kim KM, Mechoso CR, Wang G, Kucharski F, Schiro K, Hosaka M, Li S, Druyan LM, Seidou Sanda I, Thiaw W, Zeng N, Comer RE, Lim Y-K, Mahanama S, Song G, Gu Y, Hagos SM, Chin M, Schubert S, Dirmeyer P, Leung LR, Kalnay E, Kitoh A, Lu C-H, Mahowald NM, Zhang Z (2016) West African monsoon decadal variability and drought and surface-related forcings: Second West African Monsoon Modeling and Evaluation Project Experiment (WAMME II) in the Special Issue "Decadal variability of West African monsoon, external surface forcings, and their modeling". Clim Dyn. doi:10.1007/s00382-016-3224-2

Yoshioka M, Mahowald NM, Conley AJ, Collins WD, Fillmore DW, Zender CS, Coleman DB (2007) Impact of desert dust radiative forcing on sahel precipitation: relative importance of dust compared to sea surface temperature variations, vegetation changes, and greenhouse gas warming. J Clim 20(8):1445-1467

Zheng X 1997: Moist zonally-symmetric models and their applications to West African monsoons. Ph.D. thesis, Massachusetts Institute of Technology, pp 217 